\title{
MECHANISMS FOR RADIATION DAMAGE IN DNA
}

\author{
Progress Report
}

\author{
Michael 0. Sevilla \\ Oskland University \\ Rochester, Michigan
}

August 1, 1974 - July 31, 1975

Thls repost wal peepered as an teecont of work

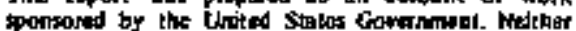

the Unitod States nor the United Slates Enviry

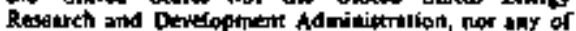

Uhelr employbes, not aty of thelr condtations,

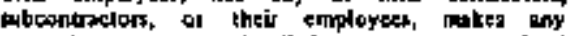

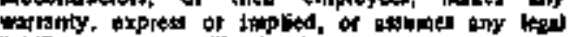

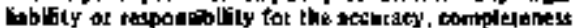

or ucefulness of any information, apparatus, prodset do

procand disctosed, or reperesepts then it, use would not

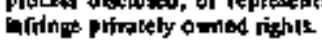

Prepared for the Division of Biomedical and Environmental Research

of the U.S. Energy Research and Development Administration under

Contract No. AT $(\mid 1-1)-2364$. 


\section{DISCLAIMER}

This report was prepared as an account of work sponsored by an agency of the United States Government. Neither the United States Government nor any agency Thereot, nor any of their employees, makes any warranty, express or implied, or assumes any legal liability or responsibility for the accuracy, completeness, or usefulness of any information, apparatus, product, or process disclosed, or represents that its use would not infringe privately owned rights. Reference herein to any specific commercial product, process, or service by trade name, trademark, manufacturer, or otherwise does not necessarily constitute or imply its endorsement, recommendation, or favoring by the United States Government or any agency thereof. The views and opinions of authors expressed herein do not necessarlly state or reflect those of the United States Government or any agency thereof. 


\section{DISCLAIMER}

Portions of this document may be illegible in electronic image products. Images are produced from the best available original document. 
"This report was prepared as an account of Government-sponsored work. Neither the United States, nor the Energy Research and Development Administration nor any person acting on behelf of the Commission.

A. Makes any warranty or representation, expressed or implied, with respect to the accuracy, completeness, or usefulness of the information contained in this report, or that the use of any Information, apparatus, method, or process disclosed in this report may not infringe privately owned rights; or

B. Assumes any liabilities with respect to the use of, or for damages resulting from the use of, any information, apparatus, method, or process disclosed in this reprort.

As used in the above, 'person acting on behalf of the Commission' includes any employee or contractor of the Administration or employee of such contractor, to the extent that such employee or contractor of the Administration employee of such contractor prepares, disseminates, or provides access to, any Information pursuant to his employment or contract with the Administration or his employment with such contractor." 
TABLE OF CONTENTS

Page

Abstract ........................... I

1. Results this year .................... 2

A. Electron Reactions with Dinucleoside Phosphate Anions. 2

B. Negative Ions of the 5-Nitropyrimidines ....... 3

c. Protonation Reactions at Carbon Sites in Anion Radicals of Certain Model Compounds and Aroma te Amino Acids. . 4

0. Positive Ions of Dinucleoside Phosphates....... 5

E. On Line Computer Capabilities . . . . . . . 5

II. Effort of the Principal Investigator . . . . . . . 7

Appendix A. The Purine DNA Base Cation and Anion Radicals: An ESR Study

Appendix B. Radicals Formed After Electron Attachment to 5-Halouracils in Aqueous Glasses

Appendix C. Electron Transfer in Dinucleoside Phosphate Anions

Appendix D. ESR Study of the Anton Radicals of 5-Nitropyrimidines

Appendix E. Protonation Reactions at Carbon sites in the Anion Radicals of Certain Unsaturated Compounds and Aromatic Amino Acids

Appendices $A$ and $B$ are reprints of work performed in the preceding Fiscal year.

Reprints \& Preprints remove. 


\section{ABSTRACT}

In this project we have proposed a mechanisms for radiation damage to ONA and detailed a series of experiments utilizing electron spin resonance spectrometry to test the proposed mechanisms. In this past year three investigations hove been completed or are nearing complet lon. These investigations are: 1. Studies of electron transfer reactions in dinucleoside phosphates 2. Studies of the anions of 5-nitropyrimidines and their reactions, and 3 . Studies of protonation resctions at carbon sites in anton raficals of certain model compounds and aromatic amino acids. In the first study, the relative electron affinities of the DNA bases were determined in a model system of the ONA strand. In addition, the study of the resctions of these anions showed that the thymine anion is the most reactive of the DNA bases in this model system. In the second study anisotropic and isotrop is spectra of the anion radicals of 5-nitropyrimidines were characterized by newly developed computer simulation programs. Several of the anions were found to react to form Iminoxy radicals, In the third study showed that protonation reactions at carbon sites in anions are reactions which are generol for molecules with unsaturated Jinkages. Thus, this mechanism is of significance to the radiolysis of many biological molecules including DNA. 


\section{RESULTS THIS YEAR}

During the past year we have made stgnificent progress in several areas. We believe that perhaps the mast significant work is described in section $A$ below. The results not only give evidence for the rale of the electron in ONA radiolysis, but they yield the relative electron aftinities of the DNA bases within a model system of the DNA strand. General descriptions of the other work performed during this year are also given below. Detailed descriptions are given in appendices C, D, and $E$.

A. Electron Reactions with Dinucleoside Phosphate Anions. Electron transfer reactions within various dinucleoside phosphate radical anions wore investigated by ESR spectroscopy to determine the relative electron affinity of the vartous DNA bases within a model system of the DNA strand. The reactions of the dinucleoside phosphate anions were also investigated in order to determine the mechanisms of reaction within this model system. Electrons are produced by photolysis of $\mathrm{K}_{4} \mathrm{Fe}(\mathrm{CN})_{6}$ in a neutral aqueous glass at $77^{\circ} \mathrm{K}$. Upon photoblesching the electrons reacted with the dinucteoside phosphate and formed the anion radical. The anions of the four DNA-nucleosides were also produced and their ESR spectra were appropriately weighted and sumned by computer to simulate the spectra found for the dinucleoside phasphate anions. From the analys is the relative amounts of each of the nucleoside anions in the dinucleoside phosphate anion were determined. For example in thymidylyl-(3' $\left.5^{\prime}\right)-2-d e o x y a d e n o s i n e(T d A)$, where the bases are likely stacked so as to allow electron transfer to the base with the grestest electron affinity, the electron is found to locslize on thymine. 
Whereas in equal mixtures of $T$ and $d A$ in which the molecules gre isolated in the aqueous medium anions of both nucleosides are found in approximately equal amounts. These results and those found for the other dinucleosides studied (TdC, TdG, dAdC, TT) clearly suggest the electron affinity of the pyrimidine bases are greater than the purine bases, however, the results are not sufficient to distinguish between the individual purine or pyrimidine bases. Upon warming thymidine containing dinucleostde phosphate anions protonation occurs at C-6 on thymine to produce the well known "thymyl" spectrum. No reactions on the other DNA bases in the dinucleoside phosphate antions were tound.

The report given in appendix $\mathrm{C}$ is a more detailed description of this mork. It is, however, a first draft of this work. Several more experiments are to be performed to clarity the relative electron affinity of cytosine.

\section{B. Negative lons of the 5-Nitropyrimidines. Mechan isms of} radiation damage to 5-nitropyrimidines have been the subject of a number of recent papers. These studtes have been motivated in part by the fact that the nitropyrimidines may be efficient radiation sensitizers. Several seemingly contradictory reports have accurred in the $1 \mathrm{iterature}$ as to the stable initial radicals formed in the radiolysis of these compounds. It was our purpose in this work to elucidate the reactions induced by the electron in 5-nitropyrimidines. We al so desired to test new expanded computer programs which simulate anisotropic spectra. (see section $C$ )

The experimental results are deseribed in detail in Appendix 0 . Briefly we found that the anion radicals were precursors to iminoxy radicals. Iminoxy radicals have been found at room temperature in single crystal work. 
In addition the computer simulations of anisotropic spectra gave detailed information in terms of $g$ values and hypertine splittings which are normally available onfy through studies in single crystals or in solution. It is our belief that the simulation of anisotropic spectra will continue to be an invaluable technique in the characterization of radicals formed in ONA subunits and DNA itself.

\section{c. Protonation Reactions at Carbon Sites in Anion Radicals of}

Certain Model Compounds and Aromat ic Amino Acids. This study was funded in part by the Petroleum Research Fund. It was undertaken because protonation reactions at carbon sites in anions are significant to the radiation chemistry of all unsaturatod compounds. As we have pointed out previously the thymine and thymidine anions have been showh to undergo a reaction of this type. This is also the most generalty accepted mechanism for the formation of the "thymyl" (5,6 dihydrothymine-5-vL) radical in ONA. Our results with the purine anions show that reactions of this type can occur for these species as well (Appendix A). The fact that the dinucleoside phosphate anions protonate on thymine is further evldence of the signiftcance of this reaction mechan ism.

The study began with a series of model compounds in order to determine the type of unsaturated molecules which readily protonzte in aqueous media. Studies of aromatic amino acids and their analogs were performed to determine it protonation occurs and at which sites they occurred. Molecular orbital calculations of the spin density and free valency showed that protonation occurred at the site of high spin density and at sites where the free valency was greater than 0.63. These calculations show that the free valency at position 6 (the stte of protonation) in thymine anion is 0.77 . The anions of the purine DNA bases which have less of a 
tendency to protonate have free valencies under 0,65 .

The results of this work suggest that free valency calculations ore able to predict the site of protonation if a reaction does occur; however, they are not sufficlent to predict whether or not rapld protonation at carbon sites wilt occur.

D. Positive lons of Dinucleoside Phosghates. Thts investigation has just begun and will perhaps constitute the major effort for the next yeer. Thus far we have been able to generate the posttive ion of thymidylyi(3'-5')-thymidine in a number of aqueous matrices. The results found suggest a reaction may occur with the ribose portion of the molecule. It this is so it suggests a mechanism for possible strand breakage in ONA. Hopefully the experiments suggested in the proposal will elucidate the mechan ism of reaction.

E. On Line Computer Capabilities. In this past year we have interfaced the Varian ESR spectrometer with an IBN JI30 computer. The analog digital converston is done by an EAl-693 converter. Through this interfacing and a number of computer programs we have developed the following capabilities:

1. To sum multiple scans of the same spectrum to decrease the noise level (the nolse level decreases by the square root of the number of scans taken.

2. To store spectra from up to 100 different radicals.

3. To add and subtract these spectra to simulste spectro in complex systems as was done in our work with dinucleoside phosphate anions. 
4. To simulate anisotropic or isotropic spectra from $g$ and $A$ tensors for comparison to experiment. These programs are capable of perform ing either rhombic or axial calculations assuming co-axial $g$ and A tensors. Thus far these simulation programs have been very helpful in the interpretation of complex anisotropic spectra. (see appendices $D$ and $E$ )

The graphic output of the computer is plotted either on a scope or a Calcomp plotter. 


\section{EFFORT OF THE PRIMCIPA! INVESTIGATOR}

The present term of this contract began August 1, 1974. The principal investigator spent the first two weeks of August on this project. Since then $20 \%$ of his time during the academic year has been spent on this work. The principal investigator will devote 9 weeks of the spring summer sessions to this project. The remining portion of the summer will be spent on related work at Lawrence Berkeley Laboratory, University of California, Berkeley. 


\section{UNI'IEU STATES \\ ENERGY RESEARCH AND DEVELOPMENT \\ ADMINISTRATION \\ CHICAGO OPERATHONS OFFICE \\ 9800 South Cass Avenue \\ Argoitne, Illinois 60439}

Apri1 29, 1975

De. Jangs th, hivarias, Dltector

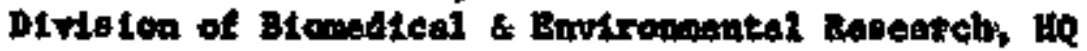

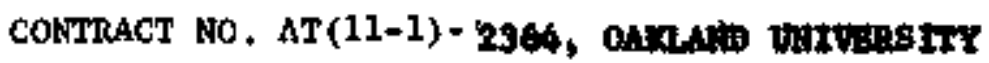

We are transmitting copies of documents submitted in accordance with our requirements covering the oubject contract.

The Contractor has included a 50-word proposed technical program which will be incorporated as the contractual scope of work. please advise me if you do not agree.

CMO: js

Harold N. Miller, Director

Contracts Management office

Enclosures:

1. Ruposal (4 e;

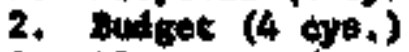

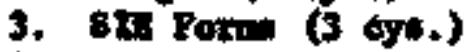

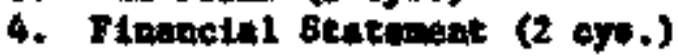

5. Exogress tepott bo. c00-2364-2 (4 c7a,)

6. Report Hos. $000-2364-3$ thrs -8 (4 579. es.)

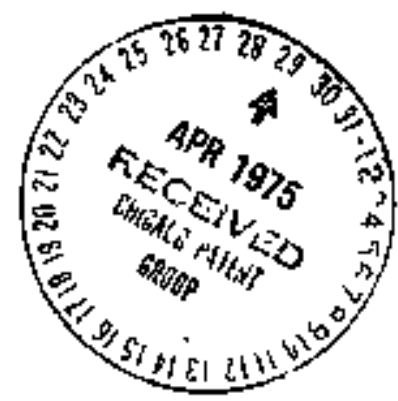

cc: CH Patent Division -w/encle, $5 \& 6$
rechuical Information Center, oak Ridge, Tenn.
(THRO CH PATENT DIVISION) -w/enale. 5 \& 6 